\title{
PENGARUH SISTEM PENGENDALIAN INTERNAL TERHADAP KUALITAS LAPORAN KEUANGAN DENGAN KOMPETENSI SUMBER DAYA MANUSIA SEBAGAI VARIABEL MODERASI" (Studi Kasus pada Pemerintahan Kabupaten Keerom)
}

\author{
Fiane Rina Sambuaga \\ fianesambuaga@gmail.com \\ Adolf Z. D. Siahay \\ asiahay1011@gmail.com \\ Syaikhul Falah \\ sehufalah@gmail.com
}

\begin{abstract}
Abstrak
This study examines the internal control system of the quality of financial statements with human resource competence as a moderating variable. The study used a survey method using a sample of civil servants in local government organizational units. The sampling method inThis study examines the internal control system of the quality of financial statements with human resource competence as a moderating variable. The study used a survey method using a sample of civil servants in local government organizational units. The sampling method in this study was purposive sampling. The data obtained were analyzed using SPSS 23 and WarpPLS 5.0. The results showed that the internal control system on the elements of the control environment had no effect and had no significant impact on the quality of the financial statements. In contrast, the element of control activities had a positive and significant effect on the quality of the financial statements. However, human resource competencies can moderate the internal control environment on the quality of financial statements. The inverse results found that human resource competencies cannot moderate internal control activities on the quality of financial statements. this study was purposive sampling. The data obtained were analyzed using SPSS 23 and WarpPLS 5.0. The results showed that the internal control system on the elements of the control environment had no effect and had no significant effect on the quality of the financial statements while the element of control activities had a positive and significant effect onof the financial statements. However, human resource competencies can moderate the internal control environment on the quality of financial statements. The inverse results found that human resource competencies cannot moderate Internal control activities on the quality of financial statements.
\end{abstract}

Keywords: Sistem Pengendalian Internal, Kompetensi Sumber Daya Manusia Dan Kualitas Laporan Keuangan

\section{PENDAHULUAN}

Peraturan Pemerintah Nomor 58 Tahun 2005 tanggal 9 Desember 2005 tentang Pengelolaan Keuangan Daerah yang merupakan peraturan pelaksanaan dari Undang Undang Nomor 17 Tahun 2003, Undang Undang nomor 1 Tahun 2004 dan Undang Undang Nomor 32 Tahun 2004 mewajibkan pemerintah daerah untuk menyusun kebijakan akuntansi (Pasal 97: Kepala daerah berdasarkan standar akuntansi pemerintahan menetapkan peraturan kepala daerah tentang kebijakan akuntansi) kemudian dalam 
Peraturan Menteri Dalam Negeri Nomor 13 Tahun 2006 tanggal 15 Mei 2006 tentang Pedoman Pengelolaan Keuangan Daerah pasal 239 ayat (1) menyatakan : Kepala daerah menetapkan peraturan kepala daerah tentang kebijakan akuntansi pemerintah daerah dengan berpedoman pada standar akuntansi pemerintahan. (Abdul Halim, 2007) menyatakan bahwa Keuangan daerah adalah semua hak dan kewajiban yang dapat dinilai dengan uang juga segala sesuatu baik berupa uang maupun barang yang dapat dijadikan kekayaan daerah sepanjang belum dimiliki atau dikuasai oleh negara atau daerah yang lebih tinggi serta pihak-pihak lain sesuai peraturan perundangan yang berlaku.

Pernyataan Standar Akuntansi Pemerintah (SPAP) No.1 juga memperjelas definisi laporan keuangan sebagai laporan yang terstruktur mengenai posisi keuangan dan transaksi yang dilakukan oleh suatu entitas pelaporan. Kualitas pelaporan keuangan dapat dilihat dari karakteristik kualitatif laporan keuangan, karakteristik kualitatif laporan keuangan menurut (PP nomor 71, 2010) tentang SAP adalah ukuran-ukuran normatif yang perlu diwujudkan dalam informasi akuntansi sehingga dapat memenuhi tujuannya. Keempat karakteristik yang merupakan prasyarat normatif agar laporan keuangan pemerintah daerah dapat memenuhi kualitas yang dikehendaki yaitu relevan, andal, dapat dibandingkan dan dapat dipahami.

Berdasarkan Undang-undang Nomor 1 tahun 2004 tentang Perbendaharaan Negara, Presiden selaku Kepala Pemerintahan diberi amanat untuk mengatur dan menyelenggarakan sistem pengendalian Internal di lingkungan pemerintahan secara menyeluruh dalam rangka meningkatkan kinerja, transparansi, dan akuntabilitas pengelolaan keuangan negara. Atas dasar peraturan tersebut, pada tanggal 28 Agustus 2008 pemerintah menerbitkan Peraturan Pemerintah Nomor 60 tahun 2008 tentang Sistem Pengendalian Internal Pemerintah (SPIP). (PP nomor 60 tahun, 2008) ini selanjutnya memberi arahan tentang konsep SPIP dan cara pelaksanaannya.

Sistem Pengendalian Internal (SPI) adalah proses yang integral pada tindakan dan kegiatan yang dilakukan secara terus menerus oleh pimpinan dan seluruh pegawai untuk memberikan keyakinan memadai atas tercapainya tujuan organisasi melalui kegiatan yang efektif dan efisien, keandalan pelaporan keuangan, pengamanan aset negara, dan ketaatan 
terhadap peraturan perundang-undangan. SPI yang diselenggarakan secara menyeluruh di lingkungan pemerintah pusat dan pemerintah daerah disebut SPI Pemerintah (SPIP). SPIP wajib dilaksanakan oleh menteri/ pimpinan lembaga, gubernur, dan bupati/ walikota untuk mencapai pengelolaan keuangan negara yang efektif, efisien, transparan, dan akuntabel. Tujuan tersebut mengisyaratkan bahwa jika dilaksanakan dengan baik dan benar, SPIP akan memberi jaminan dimana seluruh penyelenggara negara, mulai dari pimpinan hingga pegawai di instansi pemerintah, akan melaksanakan tugasnya dengan jujur dan taat pada peraturan. Akibatnya, tidak akan terjadi penyelewengan yang dapat menimbulkan kerugian negara. Ini dapat dibuktikan, misalnya, melalui laporan keuangan pemerintah yang andal dan mendapat predikat Wajar Tanpa Pengecualian.

Untuk bisa mewujudkan laporan keuangan dengan predikat Wajar Tanpa Pengecualian maka diperlukan sumber daya manusia yang berkompeten. Menurut (Spencer, LM Jr;Spencer, 1993) kompetensi merupakan karakteristik yang mendasari seseorang dan berkaitan dengan efektivitas kinerja individu dalam pekerjaannya. Kompetensi terdiri dari atas 5 (Lima) Karakteristik sebagai berikut : (1) Pengetahuan (2) kemampuan (3) sikap dan nilai yang dimiliki seseorang (4) watak yang membuat orang untuk berperilaku (5) Motivasi. Secara umum, kompetensi adalah sebuah kombinasi antara keterampilan (skill), atribut personal dan pengetahuan (knowledge) yang tercermin melalui perilaku kinerja (job behavior) yang dapat diamati, diukur dan dievaluasi.

Menurut (Warisono, 2008)mengungkapkan bahwa SKPD harus memiliki sumber daya yang kompeten, yang didukung dengan latar belakang pendidikan akuntansi, sering mengikuti pendidikan dan pelatihan dan mempunyai pengalaman dibidang keuangan dalam pengelolaan keuangan daerah yang baik. Hal tersebut diperlukan untuk menerapkan system akuntansi yang ada. Kegagalan aparatur pemerintah daerah dalam memahami dan menerapkan logika akuntansi akan berdampak pada kekeliruan laporan keuangan yang dibuat dan ketidak-sesuaian laporan dan standar yang ditetapkan pemerintah.

Opini yang diberikan atas suatu laporan keuangan pemerintah daerah merupakan gambaran kualitas akuntabilitas pengelolaan keuangan daerah, adanya kenaikan opini 
merupakan adanya perbaikan akuntabilitas dalam penyajian laporan keuangan sesuai dengan standar akuntansi pemerintahan yang berlaku. Opini tidak memberikan pendapat (TMP), Opini wajar dengan pengecualian (WDP), Opini wajar tanpa pengecualian (WTP), Opini WTP dengan paragraf penjelasan (WTP-DPP). Selain itu, bisa juga karena auditor setuju dengan suatu penyimpangan dari prinsip akuntansi yang dikeluarkan oleh Dewan Standar Akuntansi Keuangan atau adanya penekanan atas suatu hal dan bisa juga karena laporan audit yang melibatkan auditor lain.

Dilihat dari tabel 1.1 terlampir, opini yang diberikan oleh Badan Pemeriksa Keuangan terhadap laporan keuangan pemerintah daerah Kabupaten Keerom dari tahun anggaran 2012 sampai dengan tahun anggaran 2015, telah mengalami kenaikan tingkat opini yaitu opini dari tidak memberikan pendapat (TMP) yang menjadi wajar dengan pengecualian (WDP) pada tahun anggaran 2016. Hal tersebut menunjukkan bahwa laporan keuangan yang diperiksa sebagian besar pos dalam laporan keuangan, posisi keuangan, hasil usaha dan arus kas entitas tersebut telah disajikan secara wajar terbebas dari salah saji material dan sesuai dengan prinsip akuntansi yang berlaku umum di Indonesia, kecuali untuk dampak hal-hal yang berhubungan dengan yang dikecualikan untuk pos-pos tertentu disajikan secara tidak wajar. Hal ini menunjukan penurunan kualitas laporan keuangan sehingga diduga karena kurangnya sumber daya manusia yang kompeten dan memadai serta lemahnya sistem pengendalian Internal pemerintah Kabupaten Keerom.

Dalam laporan (IHPS, 2017) terdapat permasalahan kelemahan SPI terutama terjadi karena bendahara barang tidak melakukan stock opname persediaan sesuai ketentuan, Pengurus/ penyimpan barang tidak cermat menatausahakan persediaan, Pemda belum mengintegrasikan aplikasi SIMBAKDA dan SIMAKDA dan lain sebagainya. Permasalahan tersebut menyebabkan laporan keuangan pemerintah daerah Kabupaten Keerom belum dapat diberikan opini Wajar Tanpa Pengecualian (WTP) karena belum disajikannya laporan keuangan pemerintah daerah secara wajar dalam hal semua yang material, posisi keuangan dan arus kas entitas yang belum sesuai standar akuntansi 
pemerintahan, yang berdampak kepada belum memadainya sistem pengendalian Internal pemerintah daerah.

Penelitian ini mengacu kepada penelitian sebelumnya (Herawati, 2014) dengan judul pengaruh sistem pengendalian Internal terhadap kualitas laporan keuangan (survey pada organisasi perangkat daerah Pemda Cianjur). Hasil penelitian menunjukan sistem pengendalian Internal yaitu pengaruh system pengendalian Internal berpengaruh positif dan signifikan terhadap kualitas laporan keuangan pemerintah daerah sebesar $83 \%$. Secara parsial lingkungan pengendalian, penilaian resiko, kegiatan pengendalian, informasi dan komunikasi serta pemantauan berpengaruh positif terhadap kualitas laporan keuangan pemerintah daerah tetapi hanya lingkungan pengendalian, penilaian resiko dan informasi dan komunikasi yang berpengaruh signifikan terhadap kualitas laporan keuangan pemerintah daerah.

Selanjutnya (Nurillah, 2014) yang meneliti faktor-faktor yang berpengaruh terhadap kualitas laporan keuangan pemerintah daerah di kota depok, yaitu kompetensi sumber daya manusia, penerapan sistem akuntansi keuangan daerah, pemanfaatan teknologi informasi dan sistem pengendalian Internal yang hasilnya adalah bahwa kompetensi sumber daya manusia, penerapan system akuntansi keuangan daerah, pemanfaatan teknologi informasi dan system pengendalian Internal berpengaruh positif dan signifikan terhadap kualitas laporan keuangan pemerintah daerah.

Berangkat dari hasil kajian-kajian empiris diatas ternyata menunjukan adanya ambivalensi hasil penelitian. Artinya ambivalensi/ kontradiksi hasil penelitian tersebut sebenarnya adalah research gap (kesenjangan penelitian) menurut (Augusty;Ferdinand, 2011) disebutkan bahwa research gap tersebut dapat atau seharusnya dikembangkan sebagai masalah penelitian yang perlu diinvestigasi lebih lanjut. 


\section{Teori Keagenan (Agency Theory)}

Teori agensi mendasarkan pemikiran bagaimana adanya perbedaan informasi antara atasan dan bawahan atau antara kantor pusat dan kantor cabang atau adanya informasi asimetri yang mempengaruhi penggunaan sistem akuntansi (Shield, M.D, 1993) dalam Ataina (2002).

Teori keagenan mengasumsikan bahwa kinerja organisasi ditentukan oleh usaha dan pengaruh kondisi lingkungan, bahwa prinsipal adalah risk-neutral dan agen adalah risk andeffort averse. Agen dan prinsipal diasumsikan dimotivasi oleh kepentingannya sendiri dan sering kepentingan antara keduanya berbenturan (Leslie and Kren, 1997) dalam Ataina (2002). Teori ini memunculkan biaya keagenan yang merupakan pengorbanan yang timbul dari hubungan keagenan termasuk hubungan antara pihak eksekutif dan pihak legislatif.

\section{Teori Melayani (Steward Theory)}

Teori stewardship dibangun berdasarkan asumsi filosofi mengenai hakekat sifat manusia yang dapat dipercaya, mampu bertindak dan bertanggungjawab, memiliki integritas dan kejujuran untuk kepentingan publik dan stakeholder. Selanjutnya teori stewardship juga mengasumsikan bahwa terdapat hubungan yang kuat antara kesuksesan organisasi dengan kepuasan pemilik, steward akan melindungi dan memaksimalkan kinerja orgnisasi, kepentingan pemilik.

Tabel 1. Perbandingan Teori Agensi dan Teori Stewardship

\begin{tabular}{|c|c|c|c|}
\hline & \multicolumn{2}{|c|}{ Theory Agency } & Theory Stewardship \\
\hline Model of Man & $\begin{array}{l}\text { Manusia } \\
\text { berorientasi } \\
\square \quad \text { Melayani dir } \\
\end{array}$ & $\begin{array}{l}\text { Yang } \\
\text { ekonomi. } \\
\text { sendiri }\end{array}$ & $\begin{array}{ll}\square & \text { Aktualisasi Diri } \\
\square \quad \text { Melayani bersama }\end{array}$ \\
\hline Motivasi & $\begin{array}{l}\text { Kebutuhan t } \\
\text { Rendah } \\
\text { keamanan, } \\
\square \text { Ekstrinsik. } \\
\end{array}$ & $\begin{array}{l}\text { ngkat lebih } \\
\text { (psikologi, } \\
\text { konomi). }\end{array}$ & $\begin{array}{l}\text { Kebutuhan tingkat yang } \\
\text { lebih tinggi (pertumbuhan } \\
\text { prestasi, aktualisasi diri). } \\
\text { Intrinsik. }\end{array}$ \\
\hline $\begin{array}{l}\text { Perbandingan } \\
\text { Sosial } \\
\text { Identifikasi } \\
\text { Power }\end{array}$ & $\begin{array}{ll}\square & \text { Manajer lain } \\
\square & \text { Komitmen re } \\
\square & \text { Institution } \\
& \text { (legitimate, } \\
& \text { reward) }\end{array}$ & $\begin{array}{l}\text { lya } \\
\text { ndah } \\
\text { Power } \\
\text { coercive, }\end{array}$ & $\begin{array}{ll}\square & \text { Prinsipal } \\
\square & \text { Komitmen tinggi } \\
\square & \text { Personal power (expert, } \\
\text { reference). }\end{array}$ \\
\hline Orientasi resiko & $\square$ Berorientasi & control & $\square$ Berorientasi keterlibatan \\
\hline
\end{tabular}




\begin{tabular}{|l|l|l|}
\hline & \multicolumn{1}{|c|}{ Theory Agency } & \multicolumn{1}{c|}{ Theory Stewardship } \\
\hline Kerangka Waktu & $\square$ Mekanisme control & $\begin{array}{l}\text { Kepercayaa } \\
\mathrm{n}\end{array}$ \\
\hline Sasaran & $\square$ Jangka pendek & $\square$ Jangka panjang \\
\hline & $\square$ Kontrol biaya & $\square$ Mempertinggi kinerja \\
\hline Perbedaan kultur & $\begin{array}{l}\text { Individualisme } \\
\text { Rentang kekuasaan } \\
\text { Tinggi }\end{array}$ & $\begin{array}{l}\square \text { Kolektivisme } \\
\text { Rentang kekuasaan rendah }\end{array}$ \\
\hline
\end{tabular}

Sumber: Davis, Schoorman dan Donaldson (1997)

\section{New Public Management}

Konsep new public management merupakan topik yang hangat dalam reformasi sector publik, dimana prinsip-prinsip pokok dalam konsep new public management memiliki berbagai keunggulan dan kelemahan. Konsep new public management terkait dengan managemen kinerja sektor publik, oleh sebab itu pengukuran kinerja menjadi salah satu prinsip new public management(Mahmudi, 2010) Teori New public management merupakan teori managemen public yang menganggap managemen sektor swasta lebih baik daripada managemen sektor publik (Hughes, 1998) dalam (Mahmudi, 2010). Tujuan new public management adalah melakukan reinventing goverment, restrukturisasi dan pembaruan sistem birokrasi untuk memperbaiki efisiensi dan efektifitas sector publik, meningkatkan daya respon lembaga publik, mengurangi pengeluaran publik dan memperbaiki akuntabilitas managerial.

\section{PENGEMBANGAN HIPOTESIS}

\section{Hubungan Lingkungan Pengendalian dengan Kualitas Laporan Keuangan Pemerintah}

\section{Daerah}

Lingkungan pengendalian merupakan pengendalian yang mempengaruhi keseluruhan organisasi dan menjadi atmosfir individu organisasi di dalam melakukan aktivitas dan melaksanakan tanggung jawab atas pengendalian yang menjadi bagiannya. Dengan kata lain, Lingkungan Pengendalian merupakan pondasi dasar yang mendasari suatu sistem pengendalian Internal pemerintah. Apabila Lingkungan Pengendalian menunjukan kondisi yang baik, maka dapat memberi pengaruh yang cukup baik bagi suatu 
organisasi, namun sebaliknya, apabila lingkungan pengendalian jelek, mengindikasikan bahwa organisasi tersebut tidak sehat (Triyulianto, 2008).

Hal ini sejalan dengan hasil penelitian (Herawati, 2014) yang menunjukkan bahwa sistem pengendalian Internal berpengaruh positif dan signifikan terhadap kualitas laporan keuangan pemerintah daerah sebesar $83 \%$. Secara parsial lingkungan pengendalian, penilaian resiko, kegiatan pengendalian, informasi dan komunikasi serta pemantauan berpengaruh positif terhadap kualitas laporan keuangan pemerintah daerah tetapi hanya lingkungan pengendalian, penilaian resiko dan informasi dan komunikasi yang berpengaruh signifikan terhadap kualitas laporan keuangan pemerintah daerah.

Berdasarkan uraian diatas, penelitian ini dimaksudkan untuk menguji hubungan antara lingkungan pengendalian dengan kualitas laporan keuangan daerah.

$\mathrm{H}_{1}$ : Lingkungan Pengendalian Berpengaruh Positif Terhadap Kualitas Laporan Keuangan.

Hubungan Kegiatan Pengendalian dengan Kualitas Laporan Keuangan Pemerintah Daerah

Menurut (Primastuti Anindita, 2006) Aktivitas pengendalian yang relevan dengan audit atas laporan keuangan dapat digolongkan sebagai berikut: (a) Pengendalian Umum, meliputi organisasi pusat pengolahan data, prosedur dan standar untuk perubahan program, pengembangan sistem dan pengoperasian fasilitas pengolahan data. (b) Pengendalian Aplikasi, mempunyai tujuan untuk menjamin bahwa semua transaksi yang telah diproses sekali saja secara lengkap, menjamin bahwa data transaksi lengkap dan teliti, menjamin bahwa hasil pengolahan data dan transaksi benar dan sesuai keadaan, menjamin bahwa hasil pengolahan data dimanfaatkan untuk tujuan yang telah ditetapkan, dan menjamin bahwa aplikasi dapat terus menerus berfungsi.

Kajian lain yang positif namun tidak signifikan dilakukan oleh (Santoso, 2016) menjelaskan sistem pengendalian Internal pemerintah berpengaruh positif tidak signifikan terhadap akuntabilitas keuangan, pemanfaatan teknologi informasi berpengaruh positif tidak signifikan terhadap akuntabilitas keuangan dan kompetensi sumber daya manusia berpengaruh positif terhadap akuntabilitas keuangan. 
Berdasarkan uraian diatas, penelitian ini dimaksudkan untuk menguji hubungan antara kegiatan pengendalian dengan kualitas laporan keuangan daerah.

$\mathrm{H}_{2}$ : Kegiatan Pengendalian Berpengaruh Positif Terhadap Kualitas Laporan Keuangan. Hubungan Lingkungan Pengendalian, Kegiatan Pengendalian terhadap Kualitas Laporan Keuangan Pemerintah Daerah dengan Kompetensi Sumber Daya Manusia sebagai Variabel Moderating

Menurut (Warisono, 2008) mengungkapkan bahwa SKPD harus memiliki sumber daya yang kompeten, yang didukung dengan latar belakang pendidikan akuntansi, sering mengikuti pendidikan dan pelatihan dan mempunyai pengalaman dibidang keuangan dalam pengelolaan keuangan daerah yang baik. Hal tersebut diperlukan untuk menerapkan system akuntansi yang ada. Kegagalan aparatur pemerintah daerah dalam memahami dan menerapkan logika akuntansi akan berdampak pada kekeliruan laporan keuangan yang dibuat dan ketidaksesuaian laporan dan standar yang ditetapkan pemerintah. Menurut (Mardiasmo, 2009) akuntabilitas publik adalah kewajiban pihak pemegang amanah (agent) untuk memberikan pertanggungjawaban, menyajikan, melaporkan, dan mengungkapkan segala aktivitas dan kegiatan yang menjadi tanggung jawabnya kepada pihak pemberi amanah (principal) yang memiliki hak dan kewenangan untuk meminta pertanggungjawaban tersebut.

Akuntabilitas publik terdiri atas dua macam, yaitu : (1) akuntabilitas vertical (vertical accuntability), dan (2) akuntabilitas horisontal (horizontal accountability). Pertanggung jawaban vertikal (vertical accountability) adalah pertanggungjawaban atas pengelolaan dana kepada otoritas yang lebih tinggi, misalnya pertanggung jawaban unit-unit kerja (dinas) kepada pemerintah daerah, pertanggung jawaban pemerintah daerah kepada pemerintah pusat, dan pemerintah pusat kepada MPR. Pertanggung jawaban horisontal (horizontal accountability) adalah pertanggung jawaban kepada masyarakat luas. Dalam konteks organisasi pemerintah, akuntabilitas publik adalah pemberian informasi dan disclosure atas aktivitas dan kinerja finansial pemerintah kepada pihak-pihak yang berkepentingan dengan laporan tersebut. Pemerintah, baik pusat maupun daerah, harus bisa menjadi subyek pemberi informasi dalam rangka pemenuhan hak-hak publik. (Mardiasmo, 2009). Menurut 
Peraturan Menteri Dalam Negeri Nomor 13 Tahun 2006 adalah: Laporan keuangan daerah disusun untuk menyediakan informasi yang relevan mengenai posisi keuangan dan seluruh transaksi yang dilakukan oleh pemerintah daerah selama satu periode pelaporan. Menurut (Mahmudi, 2007) definisi laporan keuangan adalah: Laporan keuangan adalah informasi yang disajikan untuk membantu stakeholders dalam membuat keputusan sosial, politik dan ekonomi sehingga keputusan yang diambil bisa lebih berkualitas.

Hasil penelitian yang dilakukan oleh (Sukmaningrum, 2012) menjelaskan sistem pengendalian Internal berpengaruh positif signifikan terhadap kualitas informasi laporan keuangan daerah sedangkan kompetensi sumber daya manusia tidak berpengaruh pada pemerintahan daerah.

Hasil penelitian diatas tidak sejalan dengan penelitian yang dilakukan oleh (Nurillah, 2014) menyatakan bahwa kompetensi sumber daya manusia, penerapan sistem akuntansi keuangan daerah, pemanfaatan teknologi informasi dan sistem pengendalian Internal yang hasilnya adalah bahwa kompetensi sumber daya manusia, penerapan system akuntansi keuangan daerah, pemanfaatan teknologi informasi dan system pengendalian Internal berpengaruh positif dan signifikan terhadap kualitas laporan keuangan pemerintah daerah

Berdasarkan uraian diatas, penelitian ini dimaksudkan untuk menguji hubungan antara system pengendalian Internal dengan kualitas laporan keuangan daerah.

$\mathrm{H}_{3}$ : Lingkungan Pengendalian Berpengaruh Terhadap Kualitas Laporan Keuangan dimoderasi oleh Kompetensi Sumber Daya Manusia

$\mathrm{H}_{4}$ : Kegiatan Pengendalian Berpengaruh Terhadap Kualitas Laporan Keuangan dimoderasi oleh Kompetensi Sumber Daya Manusia

\section{METODE PENELITIAN}

\section{Populasi dan Sampel}

Populasi dalam penelitian ini adalah Organisasi Perangkat Daerah yang ada di Kabupaten Keerom yang berjumlah 30 OPD. Kriteria yang menjadi sampel penelitian ini adalah unsur pejabat yang telah menduduki jabatan minimal 1 (satu) tahun terdiri dari pimpinan SKPD, kepala bagian sub keuangan dan bendahara yang berjumlah 38 orang.

\section{Definisi Operasional}




\section{a. Kualitas Laporan Keuangan}

Kualitas laporan keuangan yang berkualitas adalah laporan yang disusun untuk menyediakan informasi posisi keuangan dan seluruh transaksi yang dilakukan oleh pemerintah daerah selama satu periode pelaporan dengan penyajian yang relevan, andal, dapat dibandingkan dan dapat dipahami.

\section{b. Lingkungan Pengendalian}

Lingkungan pengendalian merupakan pengendalian yang mempengaruhi keseluruhan organisasi dan menjadi atmosfir individu organisasi di dalam melakukan aktivitas dan melaksanakan tanggung jawab atas pengendalian yang menjadi bagiannya.

\section{c. Kegiatan Pengendalian}

Kegiatan pengendalian yang relevan dengan audit atas laporan keuangan dapat digolongkan sebagai berikut: pengendalian umum dan pengendalian aplikasi,

\section{d. Kompetensi Sumber Daya Manusia}

Sumber daya manusia (SDM) yang kompeten tersebut akan mampu memahami logika akuntansi dengan baik. Kegagalan sumber daya manusia Pemerintah Daerah dalam memahami dan menerapkan logika akuntansi akan berdampak pada kekeliruan laporan keuangan yang dibuat dan ketidaksesuaian laporan standar yang ditetapkan pemerintah.

\section{Alat Analisis data}

Alat Analisis data dalam penelitian ini menggunakan pendekatan SPPS 23 dan Structural Equation Model (SEM) dengan metode Partial Least Square (PLS) dengan menggunakan software WarpPLS 5.0. PLS-SEM digunakan untuk menguji secara simultan hubungan antar konstruk laten dalam hubungan linear ataupun non linear dengan banyak indikator baik berbentuk reflektif, formatif dan MIMIC.

\section{Evaluasi Model Pengukuran atau Outer Model}

Evaluasi model pengukuran atau Outer model dilakukan untuk menilai reabilitas dan validitas dari indikator- indikator pembentuk konstruk laten. Pengujian yang dilakukan dalam outer 
model adalah Covergent Validity dan Inner Model. Hasil pengujian hipotesis dapat dilihat pada pengujian inner model yaitu T statistic dan Path Coefficients.

\section{HASIL PENELITIAN DAN PEMBAHASAN}

\section{Pengaruh Lingkungan Pengendalian Terhadap Kualitas Laporan Keuangan}

Pengujian hipotesis $1(\mathrm{H} 1)$ yang menyatakan bahwa lingkungan pengendalian memiliki pengaruh positif dan signifikan terhadap kualitas laporan keuangan tidak terbukti. Dilihat dari hasil Output Path Coefficients and $P$ values yang menggambarkan penyajian hasil estimasi koefisien jalur (path coefficient) dan nilai p. Dari hasil pengujian diatas, terlihat nilai Path coefficients pengaruh lingkungan pengendalian terhadap kualitas laporan keuangan adalah sebesar 0,034 dan signifikan pada0,423 lebih besar dari $p<0,05$ atau $5 \%$, sehingga hipotesis yang diajukan ditolak. Hal ini berarti bahwa walaupun lingkungan pengendalian Internal yang ditetapkan sudah bagus tetapi belum diterapkan secara efektif dapat menyebabkan informasi laporan keuangan yang dihasilkan kurang tepat.

Berdasarkan hasil jawaban responden dari variabel lingkungan pengendalian dengan didasari 8 (delapan) indikator yaitu : (1) penegakan integritas dan etika, (2) komitmen terhadap kompetensi, (3) kepemimpinan yang kondusif, (4) struktur organisasi yang sesuai kebutuhan, (5) pendelegasian wewenang \& tanggungjawab, (6) kebijakan yang sehat tentang pembinaan SDM, (7) peran APIP yang efektif dan (8) hubungan kerja yang baik. Nilai tertinggi adalah 4.47 artinya banyak responden setuju dalam melaksanakan evaluasi penilaian kerja aparatur negeri sipil (ASN) guna meningkatkan komitmen terhadap kompetensi dalam lingkungan pengendalian. Sedangkan nilai rata-rata terendah adalah 3.94 yaitu aparatur negeri sipil belum menandatangani fakta integritas sehingga penegakan integritas dan nilai etika memiliki belum efektif dapat diterapkan dalam lingkungan pengendalian tersebut.

Hasil penelitian ini diperkuat dengan Laporan Hasil Pemeriksaan (LHP) BPK pada kabupaten keerom tahun 2017 yang memberikan beberapa catatan terkait lingkungan pengendalian Internal dan kualitas laporan keuangan yaitu masih terjadi kesalahan 
pengganggaran belanja barang dan jasa serta pengelolahan kas di kas daerah belum tertib. Hasil penelitian ini sejalan dengan teori (Triyulianto, 2008) yang menjelaskan bahwa lingkungan pengendalian merupakan pengendalian yang mempengaruhi keseluruhan organisasi dan menjadi atmosfir individu organisasi di dalam melakukan aktivitas dan melaksanakan tanggung jawab atas pengendalian yang menjadi bagiannya. Dengan kata lain, Lingkungan Pengendalian merupakan pondasi dasar yang mendasari suatu sistem pengendalian Internal pemerintah. Apabila Lingkungan Pengendalian menunjukan kondisi

yang baik, maka dapat memberi pengaruh yang cukup baik bagi suatu organisasi, namun sebaliknya, apabila lingkungan pengendalian jelek, mengindikasikan bahwa organisasi tersebut tidak sehat.

Hasil ini tidak sejalan dengan penelitian sebelumnya yang dilakukan oleh (Fitriani, 2007) yang menyatakan bahwa lingkungan pengendalian mempengaruhi secara signifikan terhadap kualitas laporan keuangan dimana lingkungan pengendalian yang sehat merupakan pilar utama untuk mendorong terlaksananya unsur-unsur sistem pengendalian Internal pemerintahan lainnya dalam pengelolaan keuangan daerah. Dengan demikian maka dapat disimpulkan berdasarkan hasil penelitian dilapangan bahwa sistem pengendalian Internal khususnya unsur lingkungan pengendalian tidak mempengaruhi dan tidak meningkatkan kualitas laporan keuangan pada pemerintah kabupaten keerom.

\section{Pengaruh Kegiatan Pengendalian Terhadap Kualitas Laporan Keuangan}

Pengujian hipotesis $2(\mathrm{H} 2)$ menunjukkan bahwa kegiatan pengendalian memiliki pengaruh positif dan signifikan terhadap kualitas laporan keuangan, dimana nilai Path coefficients sebesar 0.542 dengan p-value 0.001 atau lebih kecil $p<0,05$ atau $5 \%$. Sehingga hipotesis yang diajukan diterima. Hasil tersebut dapat diintepretasikan bahwa kegiatan pengendalian dapat meningkatkan kualitas laporan keuangan yang baik. Dengan kata lain, jika kegiatan pengendalian yang sudah dibuat dapat dilaksanakan dengan baik maka semakin tinggi pula pengaruhnya terhadap kualitas laporan keuangan.

Berdasarkan hasil jawaban responden dari variabel kegiatan pengendalian dengan didasari 5 (lima) indikator yaitu Review atas kinerja instansi pemerintah, (2) Pembinaan 
SDM, (3) Pengendalian pengelolaan system informasi, (4) Pengendalian fisik atas asset dan (5) Penetapan \& review indikator \& ukuran kinerja. Nilai tertinggi adalah 4.44 yaitu unsur pimpinan satuan kerja telah terlibat dalam penyusunan: rencana strategis, penetapan kinerja, rencana kinerja tahunan dan laporan kinerja Satker dan kegiatan pembinaan/ pelatihan/ pengembangan/ kompetensi SDM sudah dikomunikasikan kepada seluruh apatur sipil negara (ASN) dengan baik. Sedangkan nilai rata-rata terendah adalah 3.78 yaitu belum memiliki web/ media elektronik untuk promosi dan melaporan kegiatan satker ke masyarakat sehingga unsur pengendalian atas pengelolaan sistem informasi belum maksimal.

Hasil penelitian ini sejalan dengan Peraturan Pemerintah nomor 60 tahun 2008 pasal 18 yang menjelaskan bahwa kegiatan pengendalian Internal yang baik sekurangkurangnya melaksanakan review atas kinerja instansi pemerintah, melakukan pembinaan sumber daya manusia, melakukan pengendalian pengelolaan sistem informasi, melaksanakan pengendalian fisik atas asset, melakukan penetapan indikator ukuran kinerja, melaksanakan pemisahan fungsi, melakukan otorisasi transaksi dan kejadian penting, melakukan pencatatan yang akurat dan tepat waktu, melakukan pembatasan akses atas sumber daya, melaksanakan akuntabilitas terhadap sumber daya serat mendokumentasikan semua sistem pengendalian Internal.

Dan juga sependapat dengan penelitian terdahulu oleh (Nurillah, 2014) yang mengatakan bahwa sistem pengendalian Internal yang didalamnya termasuk kegiatan pengendalian berpengaruh positif dan signifikan terhadap kualitas laporan keuangan pada pemerintahan kabupaten depok. Namun pernyataan ini tidak sejalan dengan penelitian yang dilakukan oleh (Santoso, 2016) yang menyatakan bahwa sistem pengendalian Internal pemerintah berpengaruh positif tidak signifikan terhadap akuntabilitas laporan keuangan pada SKPD kabupaten Lampung Timur.

\section{Kompetensi Sumber Daya Manusia Sebagai Pemoderasi Pengaruh Lingkungan Pengendalian Internal Terhadap Kualitas Laporan Keuangan}

Pengujian hipotesis $3(\mathrm{H} 3)$ menunjukkan bahwa kompetensi sumber daya manusia memiliki pengaruh yang signifikan sebagai variabel moderasi $\mathrm{pada}$ sistem pengendalian 
Internal terhadap kualitas laporan keuangan, dimana nilai Path coefficients sebesar 0.323 dengan p-value 0.020 atau lebih kecil dari $p<0,05$ atau $5 \%$ sehingga hipotesis yang diajukan diterima. "Dengan kata lain kompetensi sumber daya manusia dapat memperkuat hubungan antara lingkungan pengendalian Internal terhadap kualitas laporan keuangan. Pengelolaan keuangan daerah yang baik perlu didukung dengan latar belakang pendidikan akuntansi, sering mengikuti pendidikan dan pelatihan dan mempunyai pengalaman dibidang keuangan. Hal ini diperlukan untuk menerapkan sistem akuntansi yang ada. Kegagalan sumber daya manusia akan berdampak pada kekeliruan laporan keuangan yang dibuat dan ketidaksesuaian laporan standar yang ditetapkan pemerintah."

Berdasarkan hasil jawaban responden dari variabel Kompetensi Sumber Daya Manusia dengan didasari 3 (tiga) indikator yaitu tanggung jawab, pelatihan dan pengalaman. Nilai tertinggi adalah 4.22 yaitu pedoman mengenai proses akuntansi telah dilaksanakan dengan baik. Sedangkan rata-rata nilai terendah adalah 3.97 yaitu apatur negeri sipil belum semua berpengalaman di bidang akuntansi, sehingga masih dapat memungkinkan terjadi kesalahan dalam bekerja.

Hasil penelitian diatas sejalan dengan penelitian yang dilakukan oleh (Nurillah, 2014) menyatakan bahwa kompetensi sumber daya manusia, penerapan sistem akuntansi keuangan daerah, pemanfaatan teknologi informasi dan sistem pengendalian Internal yang hasilnya adalah bahwa kompetensi sumber daya manusia, penerapan system akuntansi keuangan daerah, pemanfaatan teknologi informasi dan system pengendalian Internal berpengaruh positif dan signifikan terhadap kualitas laporan keuangan pemerintah daerah.

\section{Kompetensi Sumber Daya Manusia Sebagai Pemoderasi Pengaruh Kegiatan Pengendalian Terhadap Kualitas Laporan Keuangan}

Pengujian hipotesis $4(\mathrm{H} 4)$ menunjukkan bahwa kompetensi sumber daya manusia tidak memiliki pengaruh sebagai variabel moderasi kegiatan pengendalian terhadap kualitas laporan keuangan, dimana nilai Path coefficients sebesar -0.147 dengan $p$-value 0.189 atau lebih besar dari $\mathrm{p}<0,05$ atau $5 \%$ sehingga hipotesis yang diajukan ditolak. Hal ini berarti 
bahwa kompetensi sumber daya manusia tidak memberikan pengaruh yang kuat terhadap kegiatan pengendalian dalam meningkatkan kualitas laporan keuangan.

Berdasarkan hasil jawaban responden dari variabel kualitas laporan keuangan dengan didasari 4 (empat) indikator yaitu relevan, andal, dapat dibandingkan dan dapat dipahami. Nilai tertinggi dari kualitas laporan keuangan adalah 4.41 yaitu pernyataan bahwa penyajikan laporan keuangan telah dilaksanakan secara lengkap dan informasi keuangan yang disajikan oleh SKPD dapat dipahami oleh pengguna. Sedang nilai rata-rata terendah adalah 4.03 yaitu informasi yang disajikan oleh SKPD belum bebas dari kesalahan yang bersifat material.

Hasil penelitian ini diperkuat dengan Laporan Hasil Pemeriksaan (LHP) BPK pada kabupaten keerom tahun 2017 yang memberikan beberapa catatan terkait kompetensi sumber daya manusia, kegiatan pengendalian Internal dan kualitas laporan keuangan yaitu penatausahaan asset tidak sesuai ketentuan, penatausahaan kas di bendahara penerima belum tertib serta pengelolaan bantuan dana operasional sekolah juga belum tertib. Dengan kata lain, dapat diidentifikasikan bahwa pemerintah kabupaten keerom belum semua memiliki sumber daya manusia yang berkompeten yang didukung dari latar belakang pendidikan akuntansi serta pengalaman dibidang akuntansi dalam pengelolaan keuangan daerah sehingga kegiatan pengendalian berupa kebijakan dan prosedur yang sudah dibuat dengan bagus tidak dapat optimal diterapkan, hal ini sudah pasti akan berdampak pada informasi laporan keuangan yang kurang berkualitas.

Hasil penelitian ini sesuai dengan teori (Warisono, 2008) mengungkapkan bahwa SKPD harus memiliki sumber daya yang kompeten, yang didukung dengan latar belakang pendidikan akuntansi, sering mengikuti pendidikan dan pelatihan dan mempunyai pengalaman dibidang keuangan dalam pengelolaan keuangan daerah yang baik. Hal tersebut diperlukan untuk menerapkan system akuntansi yang ada. Kegagalan aparatur pemerintah daerah dalam memahami dan menerapkan logika akuntansi akan berdampak pada kekeliruan laporan keuangan yang dibuat dan ketidaksesuaian laporan dan standar yang ditetapkan pemerintah. 
Hasil penelitian ini sejalan dengan hasil penelitian yang dilakukan oleh (Sukmaningrum, 2012) menjelaskan sistem pengendalian Internal berpengaruh positif signifikan terhadap kualitas informasi laporan keuangan daerah sedangkan kompetensi sumber daya manusia tidak berpengaruh pada pemerintahan daerah serta dipertegas dari penelitian yang dilakukan oleh (Siahaya \& Asnawi \& Paulus, 2018) yang mengatakan bahwa kompetensi sumber daya manusia tidak memberikan dorongan yang kuat terhadap kualitas LKPD, yang secara umum memiliki makna yaitu meningkatkan variabel kompetensi tidak memilik pengaruh terhadap peningkatan kualitas LKPD.

\section{SIMPULAN}

Berdasarkan rumusan masalah, tujuan penelitian, landasan teori, hipotesis dan hasil penelitian, maka dapat disimpulkan sebagai berikut:

1. Lingkungan pengendalian tidak berpengaruh dan tidak signifikan terhadap kualitas laporan keuangan. Hasil penelitian ini diperkuat dengan Laporan Hasil Pemeriksaan (LHP) BPK pada kabupaten keerom tahun 2017 yang memberikan beberapa catatan terkait lingkungan pengendalian Internal dan kualitas laporan keuangan yaitu masih terjadi kesalahan pengganggaran belanja barang dan jasa serta pengelolahan kas di kas daerah belum tertib.

2. Kegiatan pengendalian berpengaruh dan signifikan terhadap kualitas laporan keuangan. Hasil tersebut dapat diintepretasikan bahwa kegiatan pengendalian dapat meningkatkan kualitas laporan keuangan yang baik. Dengan kata lain, jika kebijakan dan prosedur yang telah dibuat dapat dilaksanakan dengan baik maka semakin tinggi pula pengaruhnya terhadap kualitas laporan keuangan dan sebaliknya jika kebijakan dan prosedur yang telah dibuat tidak dapat dilaksanakan dengan baik maka semakin rendah pula pengaruhnya terhadap kualitas laporan keuangan.

3. Kompetensi sumber daya manusia memoderasi lingkungan pengendalian Internal terhadap kualitas laporan keuangan. Dengan kata lain kompetensi sumber daya manusia dapat memperkuat hubungan antara lingkungan pengendalian Internal terhadap kualitas 
laporan keuangan. Pengelolaan keuangan daerah yang baik perlu didukung dengan latar belakang pendidikan akuntansi, sering mengikuti pendidikan dan pelatihan dan mempunyai pengalaman dibidang keuangan. Hal ini diperlukan untuk menerapkan sistem akuntansi yang ada. Kegagalan sumber daya manusia akan berdampak pada kekeliruan laporan keuangan yang dibuat dan ketidaksesuaian laporan standar yang ditetapkan pemerintah.

Kompetensi sumber daya manusia tidak memoderasi kegiatan pengendalian Internal terhadap kualitas laporan keuangan.Hal ini berarti bahwa kompetensi sumber daya manusia tidak memperkuat hubungan antara kegiatan pengendalian Internal terhadap kualitas laporan keuangan. Hasil penelitian ini diperkuat dengan Laporan Hasil Pemeriksaan (LHP) BPK pada kabupaten keerom tahun 2017 yang memberikan beberapa catatan terkait kompetensi sumber daya manusia, kegiatan pengendalian Internal dan kualitas laporan keuangan yaitu penatausahaan asset tidak sesuai ketentuan, penatausahaan kas di bendahara penerima belum tertib serta pengelolaan bantuan dana operasional sekolah juga belum tertib. dengan kata lain, dapat diidentifikasikan bahwa pemerintah kabupaten keerom belum semua memiliki sumber daya manusia yang berkompeten yang didukung dari latar belakang pendidikan akuntansi serta pengalaman dibidang akuntansi dalam pengelolaan keuangan daerah sehingga kegiatan pengendalian berupa kebijakan dan prosedur yang sudah dibuat dengan bagus tidak dapat optimal diterapkan, hal ini sudah pasti akan berdampak pada informasi laporan keuangan yang kurang berkualitas.

\section{DAFTAR PUSTAKA}

Abdul Halim. (2007). Pengelolaan Keuangan Daerah.

Arikunto, S. (2006). Metode Penelitian Kualitatif. Jakarta: Bumi Aksara.

Augusty;Ferdinand. (2011). Metode Penelitian Manajemen. Semarang: UNDIP.

Baiman, S. (1990). A Second Look. Accounting Organizations and Society. Agency Research in Managerial Accounting, 241-371.

Baridwan, Z. (2000). Intermediate Accounting (tujuh). Yogyakarta: BPFE.

Febrianti, S. (2016). Jurnal Ekonomi Manajemen Vol. 10 No. 1, Januari 2016151 Analisis 
Pengaruh Penatausahaan Aset Tetap Terhadap Kualitas Laporan Keuangan Pemerintah Daerah Kabupaten Kubu Raya.

Fitriani, A. (2007). Lingkungan Pengendalian Internal Terhadap Kualitas Laporan Keuangan (

Survei Pada SKPD Provinsi Sulawesi Tengah )

Ghozali Imam \& Hengky Latan. (2014). Partial Least Squares: Konsep, Teknik dan Aplikasi

Menggunakan Program Smart PLS3.0 Edisi Kedua. Semarang: Universitas Diponegoro.

Hall, J. (2009). Accounting Information System. Jakarta: Salemba Empat.

Herawati, T. (2014). Pengaruh Sistem Pengendalian Internal Terhadap Kualitas Laporan

Keuangan (Survei Pada Organisasi Perangkat Daerah Pemda Cianjur)

IHPS. (2017). Indeks Hasil Pemeriksaan Semester 2 Tahun 2017, II.

Imam Ghozali. (2016). Aplikasi Analisis Multivariete Dengan Program IBM SPSS 23 (Edisi 8).

Semarang: Badan Penerbit Universitas Diponegoro.

Imam Mulyana. (2010). Sumber Daya Manusia. Jakarta: Salemba Empat.

Indriantoro, N. dan B. S. (1999). Metodologi Penelitian dan Bisnis. Yogyakarta: BPFE Yogyakarta.

Jensen, M. C., \& Meckling, W. H. (1976). Also published in Foundations of Organizational Strategy. Journal of Financial Economics, (4), 305-360.

Leslie and Kren. (1997). The Role Of Accounting Information in Organizational Control. New York: Behavioral Accounting Research.

Mahmudi. (2007). Analisis Laporan Keuangan Pemerintah Daerah. Yogyakarta: UPP STIM YKPN.

Mahmudi. (2010). Manajemen Kinerja Sektor Publik. Yogyakarta: UPP STIM YKPN.

Mardiasmo. (2009). Akuntansi Sektor Publik. Yogyakarta.

Masmudi. (2007). Laporan Keuangan Sektor Publik antara Konsep dan Praktek. Jurnal Akuntansi dan keuangan sektor publik (Vol. 3). Jakarta.

Mohammad Kasiram. (2008). Metode Penelitian Kuantitatif. Malang: UIN Malang Press.

Natalion Iban Patoding. (2018). Pengaruh Penerapan SAP berbasis akrual, kompetensi aparatur pemerintahan dan peran audit Internal terhadap kualitas laporan keuangan pemerintah daerah dengan Good governance sebagai variabel moderasi (studi pada organisasi perangkat daerah pemerintah kabupaten dogiyai).

Nurillah, A. S. (2014). Pengaruh Kompetensi Sumber Daya Manusia, Penerapan Sistem Akuntansi Keuangan Daerah (SAKD), Pemanfaatan Teknologi Informasi, dan Sistem Pengendalian Internal Terhadap Kualitas Laporan Keuangan Pemerintah Daerah (Studi Empiris pada SKPD Kota Depok).

Pasoloran, O. dan F. A. R. (2001). Teori Stewardship: Tujuan Konsep Dan Implikasinya Pada Akuntabilitas Organisasi Sektor Publik. Jurnal Bisnis Dan Akuntansi, 3(2).

Peraturan BPK RI Nomor 1. (2017). SPKN. Retrieved from http://jdih.bpk.go.id/wp- 
content/uploads/2017/01/Peraturan-BPK-Nomor-1-Tahun-2017_file-gabung.pdf

Peraturan Dalam Negeri RI Nomor 4 tahun. (2008). Pelaksanaan Reviu atas laporan keuangan pemerintah daerah.

PP nomor 71. (2010). Standar Akuntasi Pemerintah, 413.

Primastuti Anindita. (2006). Kualitas Sistem Pengendalian Internal Sebagai Penentu Tingkat Kepercayaan Laporan Keuangan Suatu Pemerintah Daerah

Robbins; Stephen. (2001). Perilaku Organisasi. Jakarta: Prentice Hall.

Santoso, E. B. (2016). Pengaruh Sistem Pengendalian Internal Pemerintah, Pemanfaatan

Teknologi Informasi Dan Kompetensi Sumber Daya Manusia Terhadap Akuntabilitas

Keuangan Daerah (Studi Empiris pada Pemerintah Kabupaten Lampung Timur).

Shield, M.D, S. M. Y. (1993). Budget Use and Managerial Performance. Budget Use and Managerial Performance, Journal of, 265-280.

Siahaya \& Asnawi \& Paulus. (2018). Pengaruh Kompetensi Sumber Daya Manusia, Sistem pengendalian Internal pemerintahan dan penerapan sistem akuntansi keuangan daerah terhadap kualitas laporan keuangan pemerintah provinsi papua, 3(110), 1-16.

Spencer, LM Jr;Spencer, S. (1993). Competence at work: Models for superior performanceCompetence at work: Models for superior performance. New York: John Wiley \& Sons.

Stenbart, R. M. B. P. J. (2014). Sistem Informasi Akuntansi (Tiga Belas). Jakarta: Salemba Empat.

Sugiyono. (2011). Metode Penelitian Kuantitatif, Kualitatif dan R\&D. Bandung: Afabeta.

Sukmaningrum, T. (2012). Laporan Keuangan Pemerintah Daerah ( Studi Empiris pada Pemerintah Kabupaten dan Kota Semarang ).

Triyulianto, T. (2008). Sistem Pengendalian Internal Pemerintah (SPIP) Bersama Kita Bisa Menyongsong Masa Depan BPKP yang Lebih Cerah, 1.

Umi Choiriyah. (2010). Information Gap Pengungkapan Lingkungan Hidup di Indonesia.

Umi Narimawati. (2008). Metodologi Penelitian Kualitatif dan Kuantitatif, Teori dan Aplikasi.

Bandung: Agung Media.

Warisono. (2008). Faktor-faktor yang mempengaruhi kinerja satuan kerja perangkat daerah

(SKPD) di lingkungan pemerintahaan jambi. Faktor-Faktor Yang Mempengaruhi Kinerja Satuan Kerja Perangkat Daerah (SKPD) Di Lingkungan Pemerintahaan Jambi.

Wibowo. (2007). Manajemen Kinerja. Jakarta: PT. Raja Grafindo Parsada.

Widodo, J. (2001). Good Governance Telaah dari Dimensi: Akuntabilitas dan Kontrol Birokrasi pada Era Desentralisasi dan Otonomi Daerah. Surabaya: Insan Cedekia. 